\title{
RESISTING INVISIBILITY
}

Detecting the Female Body in Spanish Crime Fiction 



\section{Resisting Invisibility}

Detecting the Female Body in Spanish Crime Fiction

DIANA ARAMBURU

UNIVERSITY OF TORONTO PRESS

Toronto Buffalo London 
(C) University of Toronto Press 2019

Toronto Buffalo London

utorontopress.com

Printed in Canada

ISBN 978-1-4875-0459-5

(6) Printed on acid-free, $100 \%$ post-consumer recycled

paper with vegetable-based inks.

Toronto Iberic

Library and Archives Canada Cataloguing in Publication

Title: Resisting invisibility : detecting the female body in Spanish crime fiction / Diana Aramburu.

Names: Aramburu, Diana, 1981-, author.

Series: Toronto Iberic.

Description: Series statement: Toronto Iberic | Includes bibliographical references and index.

Identifiers: Canadiana 20190050071 | ISBN 9781487504595 (hardcover)

Subjects: LCSH: Detective and mystery stories, Spanish - History and criticism. | LCSH: Suspense fiction, Spanish - History and criticism. | LCSH: Women in literature. | LCSH: Human body in literature. |

LCSH: Femininity in literature.

Classification: LCC PQ6147.D47 A73 2019 | DDC 863/.0872093522 - dc23

This book has been published with the assistance of the Asociación de Estudios de Género y Sexualidades (AEGS) and the Office of Research and College of Letters \& Science at the University of California, Davis.

University of Toronto Press acknowledges the financial assistance to its publishing program of the Canada Council for the Arts and the Ontario Arts Council, an agency of the Government of Ontario.

Canada Council for the Arts
Conseil des Arts du Canada

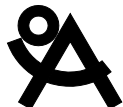


To Ana and Walter Snow 
The detective story differs from every other story in this: that the reader is only happy if he feels a fool.

G.K. Chesterton, "The Ideal Detective Story" 